\title{
Retrospective Study Of Malignant Lesions Of Head \& Neck In Rural Area Of Ahmednagar District
}

\author{
Dr. K. J Shinde ${ }^{1}$, Dr. Syed Imdad Husain Hashmi ${ }^{2}$ \\ (1. Professor \& Head, Dept of Otorhinolaryngology, Pravara Institute of Medical Sciences, Loni, India) \\ (2. Post Graduate Resident, Dept of Otorhinolaryngology, Pravara Institute of Medical Sciences, Loni, India)
}

\begin{abstract}
In India head \& neck cancers account for $30-40 \%$ of cancers at all sites. In Ahmednager district of Western India, where this study was conducted tobacco related oral cancer is very common which may be due to widespread habit of chewing tobacco. The lack of any study in this regard \& alarmingly high prevalence of head \& neck cancers in this part of India prompted us to take up this study. A retrospective study on prevalence of cancer in various head \& neck regions like oral cavity, larynx, oesophagus, oropharynx, nose \&paranasal sinuses, thyroid gland, salivary gland, nasopharynx,facial skin, eye \& ear was conducted in Dept. of Otorhinolaryngology Pravara Rural Hospital,Loni. from June 2008 to December 2011 .This study hopes to quantify \& analyze the spectrum of head \& neck cancers \& should help as a starting point for a much needed population based study in this region. A comprehensive effort is needed to identify cause of such high prevalence \& generate awareness among general masses.
\end{abstract}

Key words - Carcinomas, Head andneck cancer, Oral cavity, Total body Malignancy, Prevalence .

\section{Introduction}

Oral cancer is one of the most common cancers in the world; commonest in India Bangladesh, Srilanka, \& Pakistan. In India Head \& neck cancers account for $23 \%$ of all cancer in males and $6 \%$ in females [1].In the present study prevalence of HNCA was found to be higher than in any other studies. Carcinoma oral cavity formed the largest group. The morbidity \& mortality associated with this disease is a cause of major concern in this region. Many factors that are implicated for its causations are consumption of tobacco in its various forms, alcohol, smoking habits, lack of awareness \& lack of proper nutrition.

\section{Materials And Methods}

2.1 A retrospective study on prevalence of cancer in various head \& neck regions like oral cavity , larynx, pharynx inclusive of nasopharynx, oropharynx \&hypopharynx, oesophagus ,nasal cavity \&paranasal sinuses, Thyroid, salivary glands, Ear, Eye \& unknown primary with secondaries in neck was conducted in Department of Otorhinolaryngology Pravara Rural Hospital, LoniAhmednagar from 2008 to 2011.

2.2 Patients diagnosed in OPD \& confirmed by histopathological evaluation were included in this study.

\section{Results and Discussion}

During this 4 Years Period a total of 3140 cases of total body malignancies (TBM) were seen. Out of this 1291 cases were of malignancies of Head \& neck region. According to Various studies the prevalence of HNCA with respect to total body malignancies varies from $9.8 \%$ to $42.7 \%[2,3,4,5,6]$. In our study, the prevalence was $41.11 \%$ such high prevalence in this region is indicative of several factors that predispose to HNCA. The use of tobacco, lime, betel \& smoking is a very common oral habit prevalent in this region which may be one of the prominent causes.

The commonest HNCA obtained was oral cavity carcinomas comprising of 533 cases (41.28\%) followed by carcinoma larynx and carcinoma oesophagus comprising of 198 cases (15.33\%) and 184 cases (14.25\%) respectively [Fig. 1]. Oral cavity carcinomas comprised of $16.97 \%$ of TBM followed by Laryngeal cancers $(6.30 \%)$. In a study done in Sudan the commonest HNCA was Nasopharyngeal carcinoma (41.08\% ), followed by hypopharyngeal carcinomas (20.38\%)[7]. In Nigeria, Pakistan \& in a rural district Barshi of Solapur, Maharashtra, oral cavity malignancies were the commonest $[8,9,10]($ Table 1 ) .Carcinoma of Ear was the least common comprising of $0.16 \%$ of TBM \& $0.38 \%$ of HNCA. With respect to oral cavity, the commonest site involved was tongue (39.28\%). Carcinoma Buccal mucosa \& alveolus formed more than $40 \%$ of oral cavity malignancies and about $5 \%$ of TBM [Fig. 2]. 


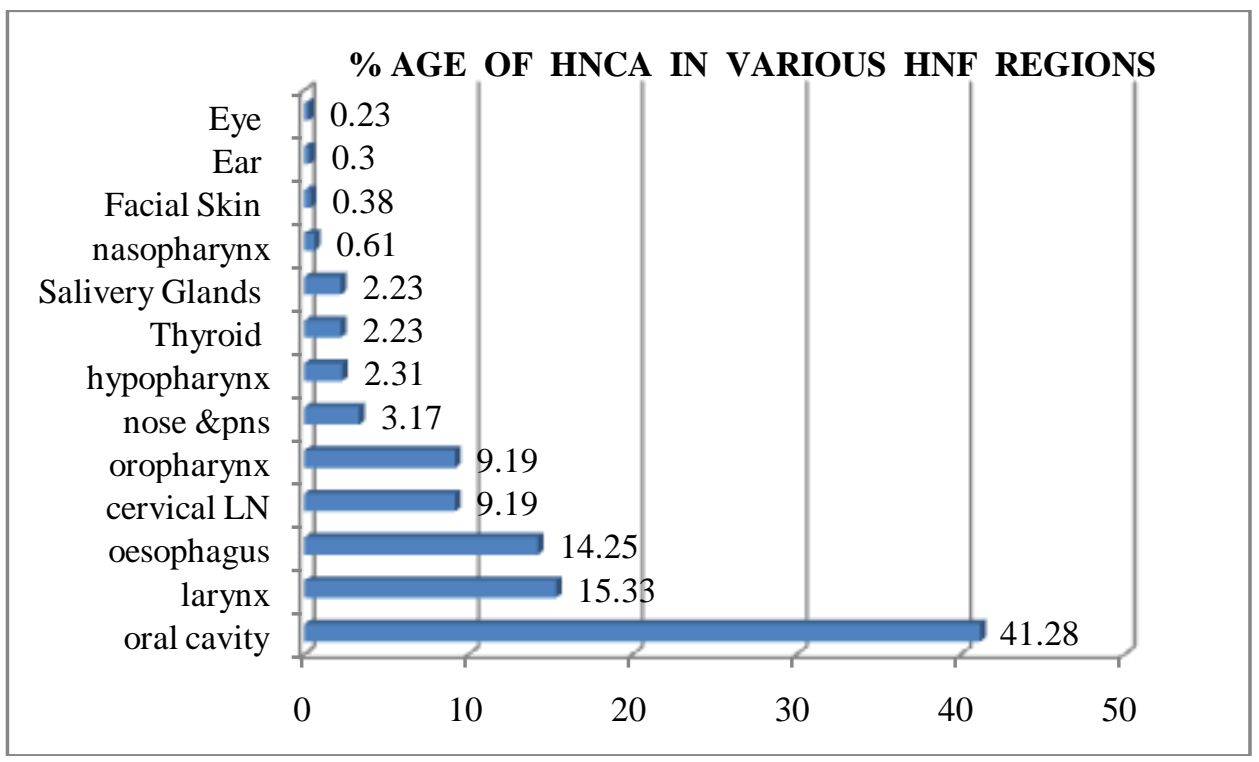

Figure 1

TABLE1 : Distribution Of \% Age Of HNCA In Various HNF Region

\begin{tabular}{|c|c|c|c|c|c|}
\hline Site & Our Study & African Countries & \multicolumn{3}{|c|}{ Asian Countries } \\
\hline & & Sudan & Nigeria & Pakistan & India ( Barshisolapur) \\
\hline Oral Cavity & $41.28 \%$ & $18.47 \%$ & $36.80 \%$ & $60.00 \%$ & $7.00 \%$ \\
\hline Larynx & $15.33 \%$ & $1.90 \%$ & $15.23 \%$ & $15.00 \%$ & \\
\hline Oesophagus & $14.25 \%$ & --- & $5.10 \%$ & ----- & ---- \\
\hline Cervical Ln & $9.19 \%$ & ------- & $26.80 \%$ & --- & $5.00 \%$ \\
\hline Orophrynx & $9.19 \%$ & $0.64 \%$ & $3.20 \%$ & $10.22 \%$ & ----- \\
\hline Nose \&Pns & $3.17 \%$ & $3.50 \%$ & $0.30 \%$ & ----- & $5.00 \%$ \\
\hline Hypopharynx & $2.31 \%$ & $20.38 \%$ & ---- & $13.55 \%$ & ------ \\
\hline Thyroid & $2.23 \%$ & ------ & $13.70 \%$ & ---- & -------- \\
\hline Salivary Glands & $2.23 \%$ & $4.78 \%$ & $1.60 \%$ & --- & ------- \\
\hline Nasophrynx & 0.62 & $41.08 \%$ & $3.20 \%$ & $1.55 \%$ & $5.00 \%$ \\
\hline Facial Skin & $0.38 \%$ & ----- & $2.20 \%$ & ------- & ----- \\
\hline Ear & $0.30 \%$ & ------ & $0.30 \%$ & ------ & ------ \\
\hline Eye & $0.23 \%$ & ---- & $4.80 \%$ & ----- & ---- \\
\hline
\end{tabular}




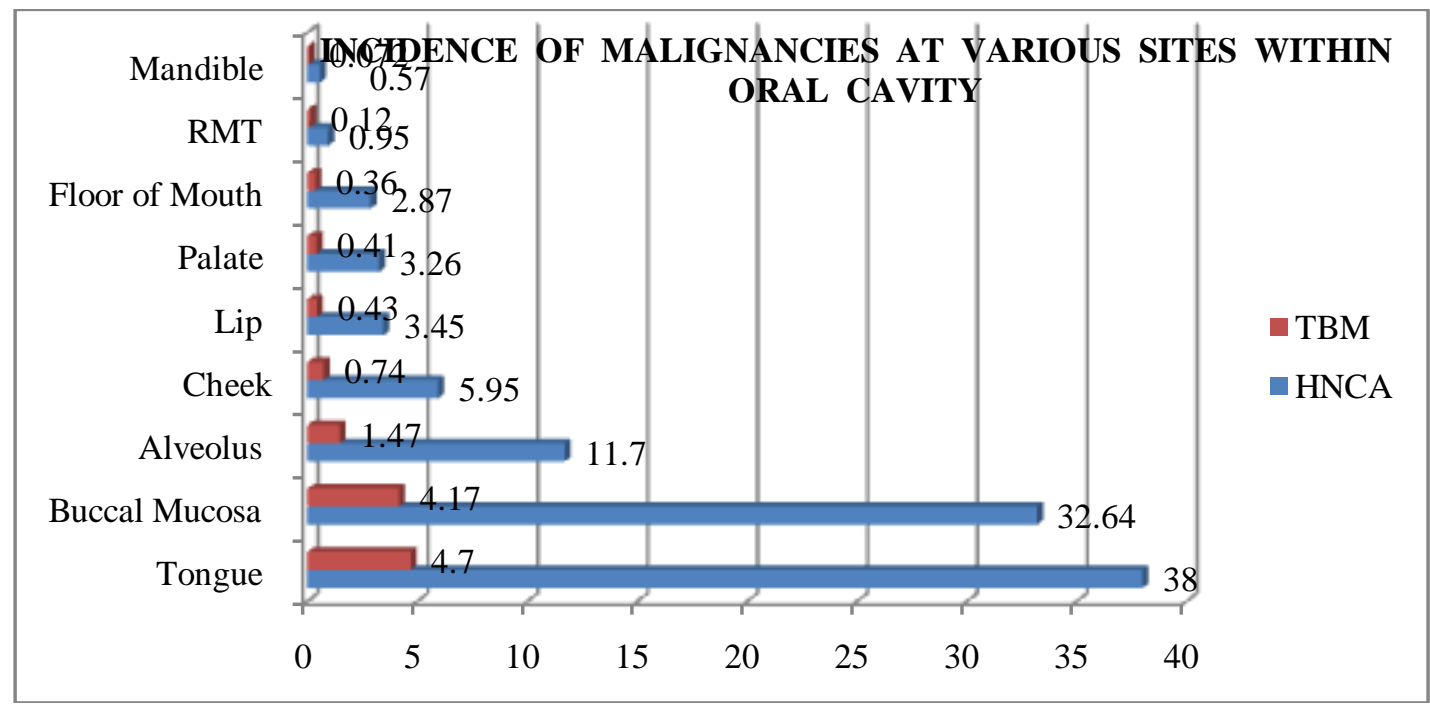

Figure 2

\subsection{Age and Gender Distribution}

The commonest age group is $6^{\text {th }}$ decade comprising of 511 cases (39.58 \%) (Table 2). 19.20\% cases were from the age group 61-70 years and $15.41 \%$ in $41-50$ years. Only less than $1 \%$ cases were below 20 year of age $(n=10)$. In contrast, in studies in African countries like Nigeria, $19.20 \%$ cases were from the age group 0-10 years[8]. In a study done in Pakistan, majority of the cases were in age group 51-60 years[9].(Table 3).

In the gender distribution male cases were far more common than female comprising of 860 males to 431 females (1.99:1) (Fig.3). Oral cavity cancer is commonest in males $(n=346)$ as well as in females $(n=187)$

This male:female ratio is in accordance with other studies ranging (1.5:1 to 2.1:1) [4,5,6]. Males formed more than $65 \%$ of oral cavity and oropharyngeal cases, the tongue $(n=210)$ being the most commonly involved site followed by buccal mucosa \& alveolus which comprised of $43.89 \%$ of all oral cavity malignancies. The male predominance is due to the fact that males are more exposed to habit of smoking \& tobacco chewing \& of their increased awareness $\&$ accessibility to health care service .

On the other hand, in females, cheek followed by tongue \& Palate were the commonest sites involved.

TABLE 2

\begin{tabular}{|c|c|c|c|c|c|c|c|c|c|c|c|c|c|c|}
\hline \begin{tabular}{|l|} 
Age \\
$(Y r s)$
\end{tabular} & $\begin{array}{c}\text { Oral } \\
\text { Cavit } \\
y\end{array}$ & $\begin{array}{c}\text { Laryn } \\
x\end{array}$ & $\begin{array}{c}\text { Oeso } \\
\text { Phagu } \\
\text { s }\end{array}$ & $\begin{array}{l}\text { cervic } \\
\text { al } L N\end{array}$ & $\begin{array}{c}\text { Oro- } \\
\text { Pharynx }\end{array}$ & $\begin{array}{c}\text { Nose } \\
\& P N \\
S\end{array}$ & $\begin{array}{c}\text { Hypo- } \\
\text { Pharyn } \\
x\end{array}$ & $\begin{array}{c}\text { Thyroi } \\
d\end{array}$ & $\begin{array}{c}\text { Saliva } \\
r y \\
\text { glands }\end{array}$ & $\begin{array}{c}\text { Naso } \\
\text { Pharynx }\end{array}$ & \begin{tabular}{|l|} 
Facia \\
l Skin
\end{tabular} & $\begin{array}{c}E a \\
r\end{array}$ & $\begin{array}{c}E y \\
e\end{array}$ & $\begin{array}{c}\text { Total } \\
(\% \text { age })\end{array}$ \\
\hline $0-10$ & 1 & 0 & 0 & 0 & 0 & 0 & 0 & 0 & 1 & 0 & 0 & 0 & 3 & $5(0.38)$ \\
\hline $\begin{array}{l}11- \\
20\end{array}$ & 0 & 1 & 1 & 0 & 1 & 2 & 0 & 0 & 0 & 1 & 0 & 0 & 0 & $6(0.46)$ \\
\hline $\begin{array}{l}21- \\
30\end{array}$ & 20 & 1 & 2 & 2 & 1 & 0 & 2 & 0 & 0 & 0 & 0 & 0 & 0 & $28(2.16)$ \\
\hline $\begin{array}{l}31- \\
40\end{array}$ & 30 & 16 & 20 & 15 & 20 & 4 & 2 & 4 & 10 & 0 & 0 & 0 & 0 & ${ }^{121(9.37}$ \\
\hline $\begin{array}{l}41- \\
50\end{array}$ & 49 & 40 & 40 & 20 & 30 & 6 & 2 & 5 & 4 & 2 & 0 & 1 & 0 & $\begin{array}{l}199(15.4 \\
1)\end{array}$ \\
\hline $\begin{array}{l}51- \\
60\end{array}$ & 250 & 50 & 60 & 60 & 40 & 11 & 17 & 10 & 4 & 2 & 4 & 3 & 0 & $\begin{array}{l}511(39.5 \\
8)\end{array}$ \\
\hline $\begin{array}{l}\text { 61- } \\
70\end{array}$ & 75 & 70 & 49 & 9 & 21 & 10 & 3 & 5 & 4 & 2 & 0 & 0 & 0 & $\begin{array}{l}248(19.2 \\
0)\end{array}$ \\
\hline $\begin{array}{l}71- \\
80\end{array}$ & 98 & 15 & 10 & 7 & 2 & 6 & 2 & 2 & 4 & 1 & 0 & 1 & 0 & $\begin{array}{l}\text { 148(11.4 } \\
\text { 6) }\end{array}$ \\
\hline $81+$ & 10 & 5 & 2 & 2 & - & 2 & 1 & 2 & 1 & 0 & 0 & 0 & 0 & $25(1.94)$ \\
\hline $\begin{array}{l}\text { Tota } \\
1\end{array}$ & 533 & 198 & 184 & 115 & 115 & 41 & 29 & 28 & 28 & 8 & 4 & 5 & 3 & 1291 \\
\hline
\end{tabular}


TABLE 4 Age Distribution of Head \& Neck Malignancies

\begin{tabular}{|c|c|c|c|}
\hline Age (Yrs & $\begin{array}{c}\text { \%age } \\
\text { Present } \\
\text { Study }\end{array}$ & $\begin{array}{c}\text { \%age } \\
\text { African } \\
\text { Country } \\
\text { Nigeria }\end{array}$ & $\begin{array}{c}\text { Asian } \\
\text { Country } \\
\text { Pakistan }\end{array}$ \\
\hline $0-10$ & $0.38 \%$ & $19.20 \%$ & $0.16 \%$ \\
\hline 11 to 20 & $0.46 \%$ & $13.70 \%$ & $0.36 \%$ \\
\hline $21-30$ & $2.16 \%$ & $11.80 \%$ & $2.01 \%$ \\
\hline $31-40$ & $9.37 \%$ & $8.30 \%$ & $5.47 \%$ \\
\hline $41-50$ & $15.41 \%$ & $16.00 \%$ & $16.07 \%$ \\
\hline $51-60$ & $39.58 \%$ & $11.80 \%$ & $40.56 \%$ \\
\hline $61-70$ & $19.20 \%$ & $12.50 \%$ & $20.14 \%$ \\
\hline $71-80$ & $11.46 \%$ & $4.50 \%$ & $14.23 \%$ \\
\hline $81-90$ & $1.94 \%$ & $1.90 \%$ & $1.00 \%$ \\
\hline$>90$ & ---- & $0.30 \%$ & ------ \\
\hline
\end{tabular}

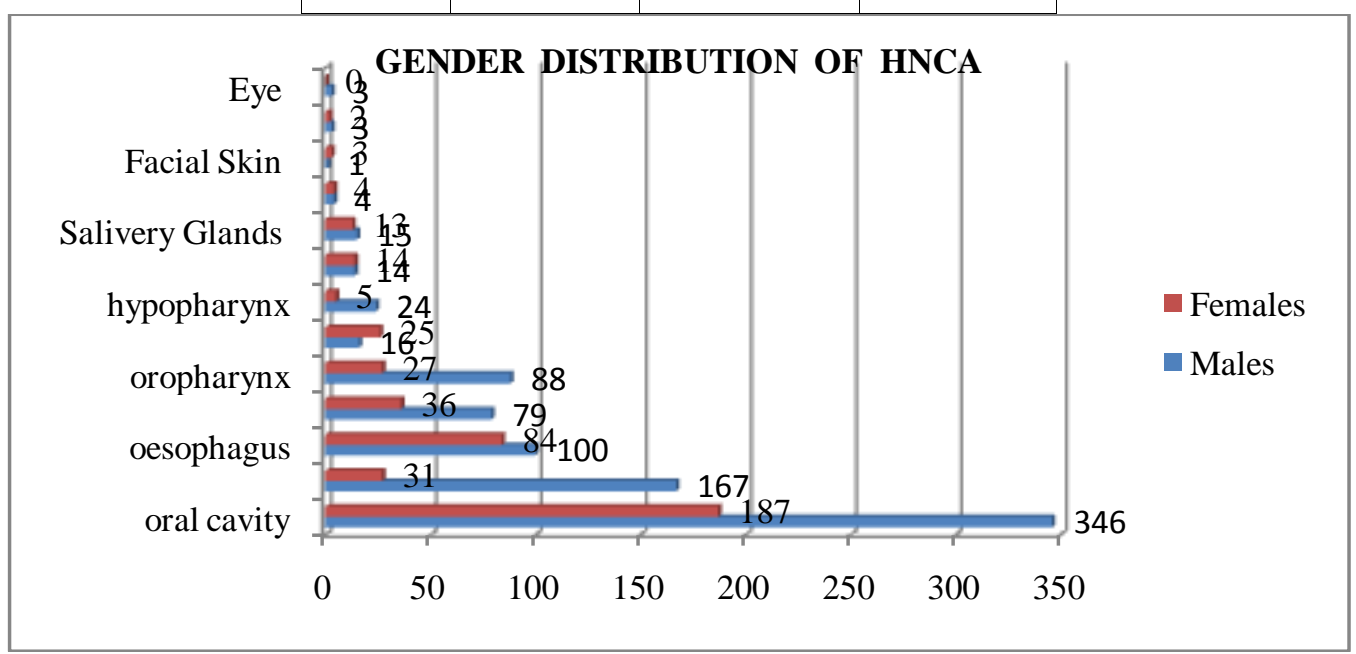

\subsection{HistopathologicalPattern :-}

Figure 3

Squamous cell carcinoma was the commonest histological type in HNCA comprising of $89.85 \%$ of total number of cases (Table 4). It is followed by Adenoid cystic carcinoma (2.09\%). Similar results were reported in other studies, values raging from $88.1 \%$ to $95.5 \%[5,11]$. SCC is also the commonest type seen is laryngeal (100\%) \&hypopharyngeal (100\%) cancers. In cancers of oral cavity, verrucous carcinoma \&acinic cell carcinoma formed only $1.9 \%$ cases, rest being SCC. 5 cases of Ameloblastoma, 2 cases of adenoid cystic carcinoma, one case of plasmacytoma were encountered SCC is also the commonest histological type seen in carcinomas ofoesophagus, nasopharynx\& nose\&paranasal sinuses . 6 cases of inverted papilloma of nose were also encountered. About $86.95 \%$ of cases of cervical lymph node cancers were found to be SCC \& rest $15 \%$ cases were Hodgkins diseases \& non hodgkins disease (Fig.4). Among thyroid malignancies, $78 \%$ of cases were papillary carcinoma, less than $22 \%$ cases comprised of follicular Adenocarcinoma \&Hurthle cell carcinoma. Adenoid cystic carcinoma comprised of $85 \%$ malignancies of both salivary glands in parotid as well as submandibular glands, rest being Acinic cell carcinoma. 3 cases of retinoblastoma eye were also diagnosed. Among facial skin malignancies $50 \%$ cases were basal cell carcinoma \& remainder Malignant melanoma [Table 4 ].In African studies done in Nigeria, commonest histological type in HNCA was Non-Hodgkins lymphoma (38.10\%) followed by Squamous cell carcinoma [8] However, In studies from Sudan, Pakistan and rural area Barshi, Solapur of Maharashtra, India, squamous cell carcinoma was the commonest histological type. $[7,9,10]$ (Table 5) 
TABLE 4

\begin{tabular}{|c|c|c|c|c|c|c|c|c|c|c|c|c|c|c|c|}
\hline $\begin{array}{c}\text { Histtopath } \\
\text { Types }\end{array}$ & $\begin{array}{l}\text { Oral } \\
\text { Cavit }\end{array}$ & $\begin{array}{c}\text { Lary } \\
n x\end{array}$ & $\begin{array}{l}\text { Oeso } \\
\text { Phag }\end{array}$ & $\begin{array}{c}\text { cervi } \\
\text { cal }\end{array}$ & $\begin{array}{l}\text { Oro- } \\
\text { Phar }\end{array}$ & $\begin{array}{l}\text { Nose } \\
\& P N\end{array}$ & $\begin{array}{l}\text { Hypo- } \\
\text { Phary }\end{array}$ & $\begin{array}{c}\text { Thyro } \\
\text { id }\end{array}$ & \multicolumn{2}{|c|}{$\begin{array}{l}\text { Salivary } \\
\text { glands }\end{array}$} & $\begin{array}{l}\text { Naso } \\
\text { Phary }\end{array}$ & $\begin{array}{c}\text { Faci } \\
\text { al }\end{array}$ & $\begin{array}{c}E a \\
r\end{array}$ & $\begin{array}{c}E y \\
e\end{array}$ & $\begin{array}{c}\text { Total } \\
\%\end{array}$ \\
\hline $\begin{array}{l}\text { Squamous } \\
\text { cell } \\
\text { carcinoma }\end{array}$ & 505 & 198 & 169 & 100 & 115 & 32 & 29 & - & $\begin{array}{l}\text { Parot } \\
\text { id }\end{array}$ & $\begin{array}{l}\text { Subma } \\
\text { ndi } \\
\text {-bular }\end{array}$ & 8 & - & 4 & - & $\begin{array}{c}1160(89 . \\
85)\end{array}$ \\
\hline $\begin{array}{l}\text { Adenocarci } \\
\text { noma }\end{array}$ & - & - & 15 & - & - & 1 & - & - & - & - & - & - & - & - & $16(1.2)$ \\
\hline $\begin{array}{l}\text { Adenoid } \\
\text { cystic } \\
\text { carcinoma }\end{array}$ & 2 & - & - & - & - & 1 & - & - & 12 & 12 & - & - & - & - & $27(2.09)$ \\
\hline $\begin{array}{l}\text { Plasmacyto } \\
\text { ma }\end{array}$ & 1 & - & - & - & - & - & - & - & - & - & - & - & - & - & $1(0.07)$ \\
\hline $\begin{array}{l}\text { Ameloblast } \\
\text { oma }\end{array}$ & 5 & - & - & - & - & - & - & - & - & - & - & - & - & - & $5(0.38)$ \\
\hline $\begin{array}{l}\text { Inverted } \\
\text { papilloma }\end{array}$ & - & - & - & - & - & 6 & - & - & - & - & - & - & - & - & $6(0.46)$ \\
\hline $\begin{array}{l}\text { Acinic cell } \\
\text { carcinoma }\end{array}$ & 10 & - & - & - & - & & - & - & 2 & 2 & - & - & - & - & $\begin{array}{c}14(1.08 \\
)\end{array}$ \\
\hline $\begin{array}{l}\text { Verrucous } \\
\text { carcinoma }\end{array}$ & 10 & - & - & - & - & 1 & - & - & - & - & - & - & - & - & $\begin{array}{c}11(0.85 \\
)\end{array}$ \\
\hline $\begin{array}{l}\text { Basal cell } \\
\text { carcinoma }\end{array}$ & - & - & - & - & - & - & - & - & - & - & - & 2 & 1 & - & $3(0.23)$ \\
\hline $\begin{array}{l}\text { Malignant } \\
\text { melanoma }\end{array}$ & - & - & - & - & - & - & - & - & - & - & - & 2 & - & - & $2(0.15)$ \\
\hline $\begin{array}{l}\text { Hodgkins } \\
\text { lymphoma }\end{array}$ & - & - & - & 10 & - & - & - & - & - & - & - & - & - & - & $\begin{array}{c}10(0.77 \\
)\end{array}$ \\
\hline $\begin{array}{l}\text { Non } \\
\text { hodgkins } \\
\text { lymphoma }\end{array}$ & - & - & - & 5 & - & - & - & - & - & - & - & - & - & - & $5(0.38)$ \\
\hline $\begin{array}{l}\text { Papillary } \\
\text { carcinoma }\end{array}$ & - & - & - & - & - & - & - & 22 & - & - & - & - & - & - & $22(1.7)$ \\
\hline $\begin{array}{l}\text { Follicular } \\
\text { adenocarci } \\
\text { noma }\end{array}$ & - & - & - & - & - & - & - & 4 & - & - & - & - & - & - & $4(0.3)$ \\
\hline $\begin{array}{l}\text { Hurthle } \\
\text { cell } \\
\text { Ocarcinoma }\end{array}$ & - & - & - & - & - & - & - & 2 & - & - & - & - & - & - & $2(0.15)$ \\
\hline $\begin{array}{l}\text { Retinoblast } \\
\text { oma }\end{array}$ & - & - & - & - & - & - & - & - & - & - & - & - & - & 3 & $3(0.23)$ \\
\hline TOTAL & 533 & 198 & 184 & 115 & 115 & 41 & 29 & 28 & & -28 & 8 & 4 & 5 & 3 & 1291 \\
\hline
\end{tabular}




\section{DISTRIBUTION OF SCC IN VARIOUS HNF MALIGNANCIES}

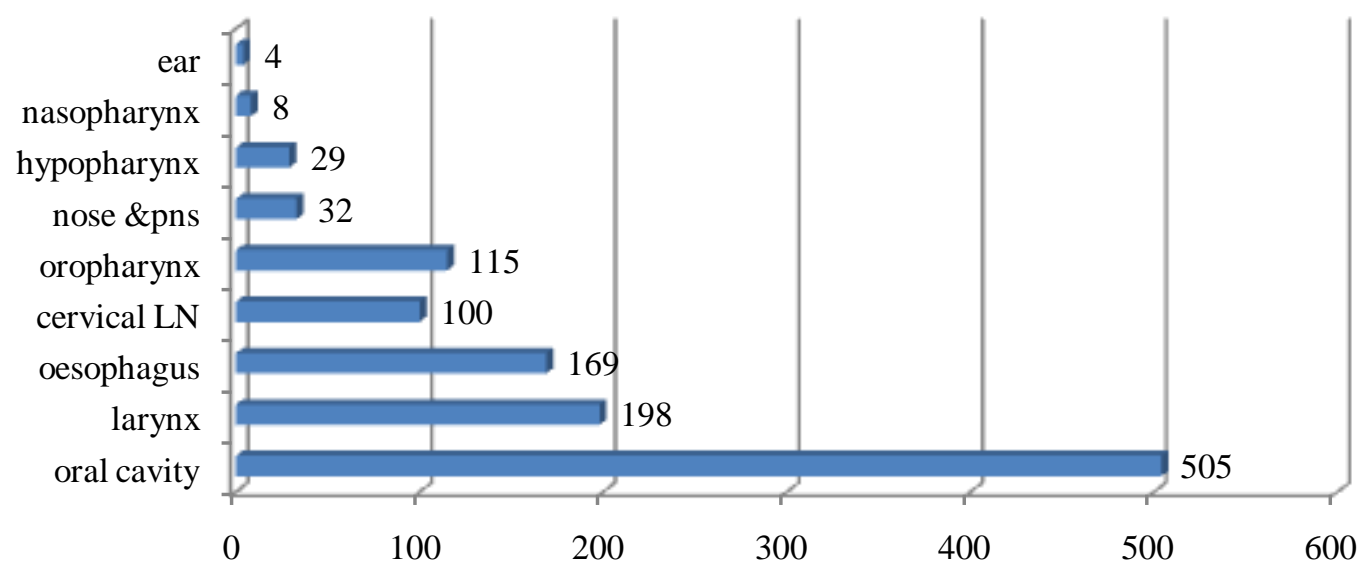

Figure 4

Table 5Histopathological Study of Hnf Malignancies

\begin{tabular}{|c|c|c|c|c|c|}
\hline \multirow[t]{2}{*}{$H P R$} & \multirow[t]{2}{*}{ Present Study } & \multicolumn{2}{|c|}{ African Countries } & \multicolumn{2}{|r|}{ Asian Countries } \\
\hline & & Sudan & Nigeria & Pakistan & Rural Dist of Maharashtra \\
\hline SCC & $89.85 \%$ & $90.77 \%$ & $25.23 \%$ & $96.50 \%$ & $97.00 \%$ \\
\hline Adeno carcinoma & $1.20 \%$ & & $7.00 \%$ & $3.50 \%$ & $3.00 \%$ \\
\hline Adenoid cystic ca & $2.09 \%$ & $5.73 \%$ & --- & --- & $\begin{array}{ll}--- \\
--\end{array}$ \\
\hline Plasmacytoma & $0.07 \%$ & 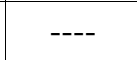 & --- & - ---- & ---- \\
\hline Inverted papilloma & $0.38 \%$ & $\begin{array}{ll}--- \\
--\end{array}$ & --- & --- & ---- \\
\hline Acinic cell ca & $0.46 \%$ & $\begin{array}{ll}--- \\
--\end{array}$ & ---- & - ---- & ---- \\
\hline Verruconsca & $0.83 \%$ & 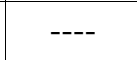 & --- & --- & --- \\
\hline $\mathrm{BCC}$ & $0.23 \%$ & $\begin{array}{ll}--- \\
--\end{array}$ & --- & ----- & 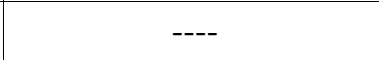 \\
\hline Malignant melanoma & $0.15 \%$ & ---- & ---- & ---- & ---- \\
\hline Hodgkins lymphoma & $0.71 \%$ & --- & $21.40 \%$ & ----- & ---- \\
\hline Non Hodgkin lymphoma & $0.38 \%$ & $3.50 \%$ & $38.10 \%$ & --- & ---- \\
\hline Papillary Ca & $1.70 \%$ & ---- & $4.00 \%$ & ----- & ---- \\
\hline Follicular Adenocarcinoma & $0.30 \%$ & --- & $3.00 \%$ & --- & ---- \\
\hline Hurthle Cell Ca & $1.50 \%$ & --- & ---- & ----- & ---- \\
\hline Retinoblastoma & $0.23 \%$ & --- & $0.00 \%$ & --- & ---- \\
\hline Sarcoma & --- & --- & $2.60 \%$ & ----- & ---- \\
\hline
\end{tabular}

\subsection{Pattern of malignancies at various sites}

3.3.1. Oral cavity is the most common site involved comprising of $16.97 \%$ of TBM and $41.28 \%$ of HNCA, male: female ratio 1.85: 1. It is also the commonest HNCA in males forming $40.23 \%$ among all males as well as $43.38 \%$ among all females and comprising $41.28 \%$ of HNCA and 16.97\% of TBM. As reported in other series, oral cavity cancers comprised of $10.2-10.5 \%$ of TBM \& 24.42 to $42.2 \%$ of HNCA $[5,6,12,13]$ with male:female ratio of $1.6: 1$ to 3.9. SCC is the most common histology seen $(94.73 \%)$. The dominant site involved was tongue ( $39.39 \%$ ).About $56.09 \%$ of cases in the study were between 41 to 60 yrs of age which is similar to findings in other studies [5,14].

3.3.2 Laryngeal carcinoma is $2^{\text {nd }}$ commonest of HNCA comprising of $6.30 \%$ of TBM \& $15.33 \%$ of HNCA. Male: female ratio $(5.38: 1)$ various workers have reported it to be $1.4-12.1 \%$ of TBM and $11.3-26.85$ 
$\%$ of HNCA [4,5,6] with m:f ratio in range of $3.34: 1$ to $11.5: 1$ [4,5,6,13,15]. Maximum no. of such cases seen between age group 41-60 yrs .

3.3.3 Oesophageal carcinoma - is $3^{\text {rd }}$ commonest accounting for $5.85 \%$ of TBM and $14.25 \%$ of HNCA .Male: female ratio ( 1.19: 1) It is reported to comprise of $3.8 \%$ to $8.1 \%$ of TBM with male: female ratio 1.3:1 to $5.1: 1[4,6,13]$.

3.3.4 Oropharyngealcancer : is the $4^{\text {th }}$ commonest HNCA comprising of $3.66 \%$ of TBM and $8.90 \%$ of HNCA. male : female ratio: $(3.25: 1$ ).Other studies ranges from $6.6 \%$ to $17.1 \%$ of HNCA with m:f ratio from $.7: 1$ to $8.3: 1[2,11]$. This may be due to tobacco chewing, smoking, \& consumption of pan masala ( flavouring agents taken along with betel leaf $\&$ betel nut ), more seen amongst males. The commonest histological type seen in such cases is SCC comprising of $100 \%$ which is higher compared to other studies $(93.3 \%$ to $98.2 \%)$ [5,6].

3.3.5Nose \& PNS - It is $5^{\text {th }}$ most common comprising of $3.17 \%$ of HNCA \& $1.30 \%$ of TBM with male: female ratio of $(0.64: 1)$ more common in females. Studies have reported carcinoma nose \&PNS in range of 0.9 $\%-2.4 \%$ of TBM $[2,5,6] \& 5.9-11.55 \%$ of HNCA [5,6,16] with m:f ratio 1.5:1-2.48 :1 [2,5] . Histologically again SCC was commonest . 6 cases of inverted papilloma\& 1 case each of adenocarcinoma, Adenoid cystic carcinoma \&Verrucous carcinoma were also encountered [Table 2 ]

3.3.6 Hypopharyngeal carcinoma is the $6^{\text {th }}$ commonest HNCA comprising of $0.92 \%$ of TBM \& $2.24 \%$ of HNCA with male :Female ratio of $4.8: 1$ which in our study is much lower as compared to other workers who have reported it to be $2.3 \%$ to $5.8 \%$ of TBM \& $11.7 \%$ to $28.3 \%$ of HNCA [5,6,11]\& male : female Ratio of $3.6: 1$ to $5.8: 1$ [6]. Here too SCC is the commonest histological type comprising of $100 \%$ cases. Maximum no.of cases were in age group $30-79$ yrs, similar to that reported in other studies [5,17].

3.3.7 Thyroid carcinoma is the $7^{\text {th }}$ commonest HNCA comprising of $0.89 \%$ TBM \& $2.16 \%$ of HNCA with male : female (1:1) .According to studies, prevalence is $0.1 \%-0.2 \%$ of TBM with m:f ratio $1: 1.8$ .Histologically commonest is papillary carcinoma followed by follicular \&hurthle cell which is similar to reports of other studies. $[18,19]$

3.3.8 Salivary gland malignancies comprise of $0.89 \%$ of TBM \& $2.16 \%$ HNCA male : female $1.15: 1$

3.3.9 Carcinoma of ear \&nasopharynxwere the least effected comprising $0.41 \%$ TBM\& $1.00 \%$ HNCA .

\section{Conclusion}

This study shows that, prevalence of head \& neck cancers is significantly high $41.11 \%$.Majority of HNCA are histologically squamous cell carcinomas affecting age group $40-69$ yrs with male outnumbering females ( $1.99: 1$ ). Therefore, HNCA constituted a major burden of total body cancers in our hospital with prevalence higher than that reported in any other studies. The highest no. of cases were of oral cavity cancers followed by laryngeal cancers, this finding is indicative of a pertinent fact that HNCA is a condition quite common in this part of country which requires prompt attention.

The increasing no. of HNCA cases is a cause of major concern as it is associated with high morbidity \& mortality in a sizeable population, factors involved are poor socio-economic conditions, oral consmption of tobacco in its various forms, use of lime with betal -leaf \&betalnuts,alcohol\& smoking habits, over \& above, lack of awareness about cancer $\&$ non-existent cancer prevention programmes have all made the scenario even worse.

This study helps to quantify \& analyze the spectrum of HNCA \& should help as a stable point for a much needed population based study in a rural area like Loni. A Comprehensive effort is needed to indentify the cause of such high prevalence, generate awareness \& treatment options suited to meet this challenge.

\section{References}

[1] Ravi Mehrotra,Mamta Singh ,Raj Kishore Gupta,Manish Singh ,Anil K Kapoor, Trends of prevalence and pathological spectrum of head and neck cancers in North India, Indian Journal of Cancer, 42(2), 2005,89-93

[2] Bhatia PL, Jha BK. Pattern of head and neck cancers in Manipur. Indian J Cancer 1982;19:241-8

[3] Padmanabhan TK, Vasudevan DM. A statistical analysis of cancer registered at the Regional CancerCentre,Trivandrum.Indian Journal of Cancer 1982;19:189-96.

[4] Jussawalla DJ, Sathe PV, Yeole BB, Natekar MV. Cancer incidence in Aurangabad city 1978-80.Indian Journal of Cancer 1984;21:55-62

[5] Manjari M, Popli R, Paul S, Gupta VP, Kaholon SK. Prevalence of oral cavity, Pharynx, larynx, nasal cavity malignancies in Amritsar, Punjab. Indian Journal of Otolaryngology Head Neck Surgery1996;48:189-96. 
[6] Thakur S, Chaturvedi V, Singh AK, Puttewar MP, Raizada RM. Pattern of ear, Nose, pharynx, larynx and esophagus (ENPLO)cancers in rural based hospital. Indian Journal of Otolaryngology Head Neck Surgery 2001;53:93-9.

[7] Abuidris DO, ElhajAHA, EltayebEA, ElgayliEM, ElMustafaOM ,Pattern of head and neck malignancies in Central Sudan -study of 314 cases .Sudan Journal of Medical Sciences 3(2),2008,105-108 .

[8] Opudo B da Lilly Tariah, Abayomi O somefun, Wasiu LAdeyemo Current evidence on the burden of head and neck cancers in Nigeria, Head and Neck Oncology 1(14),2009,1-8.

[9] YasminBhurgri, AsifBhurgri, Ahmed Usman, Shahid Pervez, NailaKayani, Imtiaz Bashir, Rashida Ahmed, Sheema H Hasan Epidemiological Review of Head and Neck cancers in Karachi ,Asia Pacific Journal Cancer 7,2006 ,195-200.

[10] J KalavathyElango,PGangadharan, S Sumithra,M A Kuriakose, Trends of Head and Neck Cancers in Urban and Rural India, Asian Pacific Journal Cancer 7,2006,108-112.

[11] Chakravarty S, Kar TK, Ghosh LM. Neoplasm of ear, nose, throat.Indian Journal of Otolaryngology Head Neck Surgery 1992; $1: 113-8$

[12] Gangadharan P. Epidemiologic observation on cancer in Indian people.Indian Journal of Cancer 1979;16:1-17.

[13] Kulkarni PV, Jaiswal SS, Rathod SB, Khalique A, Kulkarni RR. Profile of Malignancy at Ambajgai (15 years retrospective study).Indian Journal of Cancer 1996;33:31-6.

[14] Srivastava SP, Sharma SC. Gingival cancer. Indian Journal of Cancer 1968;5:89.

[15] Iwamoto H. An epidemiological study of laryngeal cancer in Japan (1960-69).Laryngoscope (1975);85:1162.

[16] Thakur S, Chaturvedi V, Singh AK, Puttewar MP, Raizada RM. Pattern of ear, Nose, pharynx, larynx and esophagus (ENPLO)cancers in rural based hospital. Indian Journal of Otolaryngology Head Neck Surgery2001,53:93-9.

[17] Sawai MM, Tawalkar GV, Gangadharan P. Cancer nasopharynx - A review of 1036 Cases seen at Tata Memorial Hospital, Bombay. Indian Journal of Cancer 1983;20:89.

[18] RaoDN .Epidemiological observations of thyroid cancer : Shah AH, Samuel AM, Rao RS, editors . Thyroid Cancer - An Indian Perspective Mumbai Quest Publications ; 1999 . p.3-16

[19] Gangadharen P ,Nair MK, Pradeep VM , Thyroid Cancer in Kerala In : Shah AH, Samuel AM, Rao RS , editors : Thyroid cancer An Indian Perspective Mumbai Quest Publications ; 1999 p. 17- 32 